\title{
A PEACEFUL SOLUTION TO THE NUCLEAR TENSION IN THE KOREAN PENINSULA
}

Gloria Milena Torres Rojas ${ }^{(a)}$

UNA SOLUCIÓN PACÍFICA A LA TENSIÓN

NUCLEAR EN LA PENÍNSULA DE COREA

UMA SOLUÇÃO PACÍFICA PARA A TENSÃO

NUCLEAR NA PENÎNSULA COREANA

Fecha de recepción: 01 de diciembre del 2019

Fecha de aprobación: 22 de abril del 2020

Disponible en línea: 29 de mayo del 2020

Sugerencia de citación: Torres Rojas, G. M. (2020). A peaceful solution to the nuclear tension in the Korean peninsula. Razón Crítica, 9, 187-199. doi: 10.21789/25007807.1554

(a) Gloria Milena Torres Rojas

PhD in International Law, Xiamen University (China, 厦门大学), Chinese Government Scholarship Awardee. MSc in International Relations, (外交学院). MSc in Politics, Economic and International Affairs, Externado University (Bogotá, Colombia) and IHEAL (Paris, France).

Professor of law and international affairs and researcher at the Colombian Ministry of Defense, National Police, Colombia.

pomarito1981@gmail.com

https://orcid.org/0000-0002-9679-3302 


\section{A B S T R A C T}

In spite of the efforts of the international community to solve the Democratic People's Republic of Korea (DPRK) nuclear crisis, this issue remains unsolved. The relevance of this matter lies in the need to find a permanent solution to the crisis that leads to a total denuclearization of the Korean Peninsula. Therefore, the aim of this article is to demonstrate the need of a peaceful solution to the DPRK nuclear issue, in which the security concerns of North Korea are addressed by signing a peace treaty that ensures that the United States will not attack the regime, will remove its troops from South Korea, and will finish its military drills with this ally. This article will discuss what elements will be necessary to achieve a peaceful solution to this nuclear conundrum.

KEYWORDS: North Korea, nuclear weapons, preventive strike, proliferation, use of force. 


\section{R E S U M E N}

A pesar de los esfuerzos de la comunidad internacional para solucionar la crisis nuclear en la República Popular Democrática de Corea (RPDC), esta situación sigue sin resolverse. La relevancia de esta problemática radica en la necesidad de encontrar una solución permanente que conduzca a la desnuclearización total de la península de Corea. Por ello, el objetivo de este artículo es demostrar por qué se requiere una solución pacífica al problema nuclear que supone la RPDC, donde se aborden las preocupaciones de seguridad de Corea del Norte mediante la firma de un tratado de paz con Pyongyang, el cual deberá garantizar que Estados Unidos no atacará al régimen, removerá sus tropas de Corea del Sur y terminará sus ejercicios militares con este país aliado. El presente documento discutirá los elementos necesarios para lograr una solución pacífica al enigma nuclear en esta parte del mundo.

PALABRAS CLAVES: Corea del Norte, armas nucleares, ataque preventivo, proliferación, uso de la fuerza.

\section{R E S U M O}

Apesar dos esforços da comunidade internacional para solucionar a crise nuclear da República Popular Democrática da Coreia (RPDC), ela permanece sem solução. A relevância dessa questão reside na necessidade de encontrar uma solução permanente para a crise que leve à desnuclearização total da península coreana. Nesse sentido, o objetivo deste artigo é demonstrar por que é necessária uma solução pacífica para a questão nuclear da RPDC em que as preocupações com a segurança da Coreia do Norte sejam resolvidas pela assinatura de um tratado de paz com Pyongyang, no qual os Estados Unidos garantem que não atacarão o regime e que removerão suas tropas da Coreia do Sul, bem como terminarão seus exercícios militares com seu aliado. Este artigo discutirá quais elementos serão necessários para alcançar uma solução pacífica para a tensão nuclear.

PALAVRAS-CHAVE: Coreia do Norte, armas nucleares, ataque preventivo, proliferação, uso da força. 


\section{N T R O D U C T I O N}

Before addressing what elements and issues will be necessary to achieve the aim of a peaceful solution to the Democratic People's Republic of Korea (DPRK) nuclear crisis, it is important to mention how this article will be organized. In the first place, it will deal with important elements to be considered when dealing with DPRK by using the Neorealist Theory of international relations. Secondly, it will explain what will be the contain of the Peace Treaty among North Korea, the United States (US), South Korea, China, and the International Atomic Energy Agency (IAEA). Thirdly, it will discuss some measures to bring about peace on the peninsula. Finally, it will present some conclusions.

\section{WHAT ELEMENTS AND ISSUES WILL BE NECESSARY TO ACHIEVE THE GOAL OF PEACE ON THE KOREAN PENINSULA?}

In order to propose what elements will be necessary to achieve the goal of peace on the Korean Peninsula, it is important to know first what the US and North Korea want from each other.

Regarding North Korea, the aim of the regime is its survival. Given that the international system is characterized anarchy, as Waltz proposes, it is imperative for states to strive for their security. The interpretation of Alexander Wendt regarding this neorealist world is that, considering the anarchy of the international system and the absence of a Leviathan, in which states can rely on so as to guarantee their security, this situation compels states to dissuade any attack by trying to catch up on the capabilities of its adversaries by enhancing its own power or recruiting allies (Wendt, 1999). 
This preposition could explain why North Korea is pursuing nuclear weapons, since, as Waltz states, these contribute to the absence of war and the preservation of stability. In the case of the DPRK, its desire to deter an attack from the United States is absolutely clear. For this country, the United States is a threat for its survival; that explains their interest in having nuclear weapons. DPRK goals seem to be: reach strategic parity with the US by creating a credible nuclear deterrent and compelling opponents to conclude a peace treaty, recognize the sovereignty and independence of the DPRK, and provide security guarantees to enable the country's further economic development (Toloraya, 2017). The US priority on North Korea is to achieve the total denuclearization of the regime.

Taking into the account the interests of both parties, a peaceful solution to the nuclear crisis will be not only the denuclearization of the Korean Peninsula but also the signing of the peace treaty so as to deal with the security concerns of Pyongyang. A peace treaty must be based on trust, as Choe Chang explains. So, as to create thrust among North Korea and the United States, it is of paramount importance the conclusion of a peace treaty that finalizes the prevailing state of war and puts an end to the animosity among both countries. For this author, any accord that neglects the question of war and peace will fail. Chang concludes by asserting that the signal of a peace treaty is not only an issue of one actor giving advantages to the other or giving compensation, it is an issue of political relevance that will be good of everybody, especially the DPRK, the US and the community of states (Chang, 2010).

\section{WHAT WILL BE THE CONTAIN OF THE PEACE TREATY AMONG BOTH PARTIES?}

To answer this question, it is appropriate to consider that regarding the elements of a treaty with North Korea, a peace treaty with this country would involve the verified dismantlement of its weapons program and credible security assurances that it will not be attacked or otherwise destabilized, including the removal of US troops from South Korea and the end of joint US-South Korea military exercises. It is also imperative the verified cessation of North Korean threats and conventional military preparations against the South, the removal of economic sanctions against North Korea, and, finally, an agreement to address the question of territorial integrity in the Korean Peninsula through diplomatic means (Jaramillo, 2018). 
The first element, the verified dismantlement of North Korean weapons program, will require an active participation of the International Atomic Energy Agency (IAEA). It is important to consider that this has already been done on the sense that such agency has expressed its willingness to verify the process of DPRK's denuclearization. In this way, the IAEA has declared to be ready to undertake any verification activities in the DPRK requested by the countries concerned, subject to authorization by IAEA's Board of Governors.

The verification of the dismantlement requires not only that the IAEA carries out their duties, but also DPRK cooperation in restraining from any conduct to hinder the process. In this sense, in any eventual peace treaty, the DPRK has to pledge to facilitate the IAEA verification tasks and promise not to interfere in this process, as occurred in the past when the country obstructed IAEA inspections by expelling its inspectors (Sputnik News, 2018).

The second element credible of security assurances that North Korea will not be attacked is the most important element of any peace treaty, because if those security guarantees are provided, the DPRK will be willing to give up its nuclear programs. For this, is imperative not only the suspension of US and South Korea military drills, but their definite termination. This is because, as it is well known, joint military drills between the US and South Korea are a "provocation" for North Korea, as well as a preparation for an invasion (Breuninger, 2018). For this reason, as Jaramillo says, North Korea would also need assurances about US military intentions. The sizable US military contingent south of the DMZ, its joint military exercises with South Korea, and its deployment of the THADD ballistic missile interceptor system would need to be part of any grand bargain (Jaramillo, 2018).

The steps toward a peaceful solution not only depend on the US and South Korea, but also on the DPRK. In this sense, North Korea has to promise it will end its threats against the United States and its neighbors, so as to accomplish this, it will be advisable Chinese aid on this. China could be a guarantor so that North Korea stops its defying behavior, suspending its aid in case North Korea continues issuing threats and challenging military preparations against its neighbors. Many scholars dismiss the Chinese influence on DPRK. However, it is undeniable that China still exerts influence on Pyongyang if we consider that China is North Korea's most important trading partner and main source of food and energy (Albert, 2018). 
With relation to the removal of sanctions, this point is critical, considering that sanctions with a closed country such as North Korea do not work. Instead of inflicting pain on the DPRK regime, sanctions inflict suffering on the North Korean people. Moreover, sanctions have not dissuaded North Korea from enhancing its nuclear program. On the contrary, the country has developed its nuclear weapons program and has a modern ballistic missile program with the capability to hit the US. Therefore, in a possible peace treaty among this nations, the removal of sanctions and assuring North Korea's insertion within the international community by means of economic and diplomatic relations becomes imperative.

Regarding the last point of an eventual peace treaty, namely the question of territorial integrity in the Korean peninsula, according to Jaramillo, the scope and definition of this goal are critical. If denuclearization is pursued in isolation, North Korea's reluctance to engage in negotiations will remain strong (Jaramillo, 2018). For this reason, it is essential to deal with DPRK security issues, especially the military drills that threaten the DPRK survival. Regarding this particular issue, I share Von Pan Zhenqiang view that a solution requires a roadmap that should have an immediate focus on curbing the fast-deteriorating situation in the peninsula. The best way to this end is perhaps that each side should refrain from acting in whatever way that aggravates the tension. Any new agreement should use the previous accord as a blueprint and have some improvements so as to reassure the obligation of North Korea to remain non-nuclear and to terminate all its nuclear programs in a verifiably way. In return, North Korea's security concerns and the need for economic assistance must be met by the US in an acceptable way to both Pyongyang and Washington. In short, a new agreement should include obligations by both the DPRK and the US in a balanced and verifiable manner (Zhengqiang, 2003).

\section{OTHER MEASURES TO BRING ABOUT PEACE}

The author of this article believes that is still possible to use a peaceful way to solve the DPRK nuclear crisis. However, sharing the view of the interviewed scholar García, the progress of negotiations depends on the willingness of nuclear powers to halt their nuclear tests and begin to reduce their arsenals. Without the example of the big powers, the emergent nuclear powers will continue to have excuses for pursuing clandestine nuclear programs. According to García, the solution to the 
DPRK nuclear crisis implies discussion and a multilateral arrangement that overcomes the odious distinction between first-class countries (those entitled to possess nuclear weapons) and second-class nations, that is, the others. This discriminatory solution led the essays and the possession of atomic bombs by Israel, India, and Pakistan. As long as double standards exist, the atomic club and the multilateral institutions will not have the moral authority to impede Iran, North Korea and other countries from possessing atomic bombs (García, 2015). I totally agree with the cited author on the sense that as long as there are double standards, in which some countries are allow to have nuclear weapons and others who do not, it will be aimless to demand North Korea to denuclearize, especially taking into account that through history the US not only has established nuclear weapons on South Korea, but it has also threaten North Korea with their use. On this regard, we have to recall that recently declassified US documents revealed the US plan of a nuclear attack against the DPRK in 1969 in the wake of the EC 121 incident (Chang, 2010). For this reason, it is important to reduce the fear of North Korea, as Doug Bandow states, by taking steps that reduce the Kim regime's paranoia and insecurity, thus decreasing impetus for tougher repression. While a more secure Kim might feel free to abuse his population, he would face less pressure to do so from fear of upheaval. Increasing the regime's sense of security may be a necessary — if not a sufficient — condition for improvement (Bandow, 2017).

I agree with scholar Pio García that after guaranteeing the survival of the regime another step forward to defuse the nuclear crisis implies a bilateral negotiation process between the two Koreas and DPRK neighbor's countries such as China, Russia and Japan, and the Security Council; specifically scheme of negotiations composed by 8 parties, which combines the experiences of the Six Party Talks and the negotiation of the Security Council, the IAEA, and Germany with Iran, which concluded in the 2015 Agreement. In my perspective, the Iran Nuclear Agreement could be an example to bring about denuclearization on the Korean Peninsula and it will be useful as a beginning to sow peace in the region. According to a technician from the IAEA, Iran has the most inspected nuclear program in the world. IAEA inspectors have access to $100 \%$ of atomic facilities and certified Iranian commitment compliance (Hurtado, 2017). Given the success of the Iranian nuclear deal, even if the US has left the accord, the IAEA can also guarantee the inspection of North Korean nuclear program and complete access to its atomic facilities. Equally to the Iranian 
nuclear deal, a deal with the DPRK would help to eliminate the concerns and suspicions of the US vis a vis North Korea, by means of building trust measures among the parties conducive to a sustainable peace. One alternative on this sense would by giving DPRK benefits so that this country fulfills its promises. The US has to take North Korea as an equal sovereign state and address its concern for security and development (Ying, 2017).

For the success of the deal it is necessary not only that North Korea takes steps towards denuclearizing, but also that the United States stick to its compromises, considering that in the past the US violated its compromises vis a vis DPRK. About this situation, we have to recall that despite both countries signed the Framework Agreement of 1994, the US did not fulfilled its part of the deal if we consider that the lightwater reactors offered to North Korea were never built and the Hawkish Republicans in Congress derided the framework (Ryan, 2017). In the same way, in the case with Iran, the United States pulled out of the nuclear deal achieved with Teheran in 2015, although Iran implemented the commitments undertaken in the nuclear deal, according to the IAEA.

The fact that the United States did not abide by the Iran nuclear deal, probably sent a message to North Korea and to the international community that the US cannot be trusted. Hence, it is necessary that in the nuclear deal with North Korea, Washington sticks to its promise of providing security guarantees for the regime. Unfortunately, the deal achieved on June 12, 2018, does not mention anything about the content of those guarantees and how the US will fulfill their commitments. According to political analysts, the accord of June 12 was more something symbolic than tangible and it is not clear if future negotiations will lead to the ultimate goal of denuclearization, said Anthony Ruggiero, a researcher at the Foundation for the Defense of Democracies in Washington.

In spite of the loopholes of the Accord of June 12, 2018, we can state that, at least, the parts achieved a step forward towards denuclearization of the Korean Peninsula that on the surface are contributing to sow peace on the Northeast Asian region. It is important to state that the US had made important concessions to defuse tensions according to those dissatisfied with the Joint Communique. For instance, the US changed its initial position in which it stated that so as to establish negotiation with DPRK, the country had to denuclearized in a complete, verifiable and irreversible. Finally, Washington changed its position on this issue maybe because it realized that denuclearization of the Korean peninsula is something that requires time and that it is not realistic to expect that DPRK would give up 
its nuclear arsenal in the same way as Libya did in 2003, which lead to the overthrowing of Gadhafi afterwards by a coalition headed by NATO.

Perhaps, the US administration realized that the Libyan model was not to be followed in North Korea and thus adopted a flexible and more realist approach vis a vis North Korea, in which it agreed a phase denuclearization process, creating a window of opportunity for the solution of the nuclear crisis. It seems that the steps on this direction are already taken. In fact, it seems that the US is following the recommendations of the panel of experts of Stanford University, who suggested of a halt, roll back and eliminate approach in which the most important initial steps to take toward denuclearization to be: no nuclear tests, no intermediate or longrange missile tests, no more production of plutonium and highly enriched uranium, and no export of nuclear weapons, materials or technologies (Hecker, 2018).

In my view, both an accord similar to the Iran Nuclear deal, taking as a base the 1994 Agreed Framework, and the halt, roll back and eliminate approach, suggested by the University of Stanford, are realistic approaches that will bring about in the long-term denuclearization if involved parties create trust among them and fulfill their compromises in good faith. It is important to state that, up to now, North Korea seems to stick to this program because it has halted its nuclear tests and missiles tests and appears to have started dismantling key facilities at its main satellite launch site, in a step toward fulfilling a commitment made by leader Kim Jong un at his summit with president Donald Trump in June 2018 (Tong, 2018). All this shows the benefits of negotiations and the importance to achieve a peaceful solution to the Nuclear crisis. Even though we cannot state that peace has arrived definitely to the Korean peninsula, at least the US, North Korea, and South Korea have taken steps on the right direction when they met first in Panmunjom on April 27, 2018, and later at the Summit in Singapore on June 12, 2018. Now, everything will depend on how the parties will build trust measures, which, according to Choi Jinwook, are aimed at normalizing relations, building sustainable peace and lay the cornerstone for eventual unification on the Korean Peninsula (Jinwook, 2013). It is up to the parties to implement the measures to achieve those goals.

In conclusion, a peaceful solution to solve this nuclear conundrum implies first to know what the parts want from the negotiation and, afterwards, meet the interests and expectations of the parties. In the case of North Korea, is clear the desire for a peace treaty that finishes 
the state of war that up to now prevails on the Korean peninsula. A longlasting peace treaty is needed to replace the 50-year truce and stop the unfinished war on the peninsula (Zhengqiang, 2003). In the case of the US, it wants denuclearization of the Korean peninsula, and to delete the ambiguities that surround the nuclear crisis in North Korea. One of these ambiguities, for example, is the real status of North Koreas nuclear capability. For instance, there is little knowledge about the purpose, nature and scope of North Korean uranium program. Again, views on the objective of Pyongyang with regard to its nuclear program are divided (Zhengqiang, 2003).

Taking into consideration the interests of both sides, the next step is how to reconcile such interests. The proposal of the author of this article is that in case negotiations stall again, as in the past, the parties must reach a new agreement taking as a model the Iran Nuclear deal of 2015, which, in my opinion, was a good accord, if we consider the view of Tamem Hassanali, who says it was rational, allowed inspections in Iran by the IAEA, and ensured there were stringent measures and controls in place to prevent Iran from developing a nuclear weapon for the next 15 years (Hassanali, 2017). In the same way as in Iran, a similar deal will allow inspections on Pyongyang and guarantee that the regime will stop from enhancing its nuclear capabilities. A similar deal to that reached with Iran combined by the halt, roll back and eliminate approach suggested at Stanford University are models that will lead to achieve peace on the Peninsula, since both proposals are based on realistic expectations, take into account the interests of all parties, and could contribute to achieve the goal of denuclearizing the peninsula. It is important to state that not only is necessary to achieve a deal in a way towards a peaceful solution, but it is also relevant to eliminate the double standards that prevail in the international arena by making that the "big powers" work towards a reduction of their nuclear arsenal. In this way, nuclear states such as North Korea, India, and Pakistan will be motivated to eliminate their nuclear weapons. Consequently, if double standards are eliminated and the international organizations responsible of verifying denuclearization, such as the IAEA, are dotted with a coactive and sanctioning capacity, it will be easier that involved parts fulfill their compromises.

We cannot dismiss that the Korean nuclear issue calls for reflections on a new order in Northeast Asia (Ying, 2017). Therefore, a new security framework that contributes to establish peace in the region is required. In order to accomplish this task, China is called to play an 
active role in building a new order, so as to attain common security in the region. Perhaps, the resolution of the DPRK nuclear crisis in a peaceful way and the establishment of a free nuclear zone in the region can contribute to build the basis of this project. The Chinese role is necessary in any peaceful solution, since the Asian Dragon has been an important stakeholder from the beginning of the crisis, in 2003. Many authors claim that China is not any longer North Korea's big brother. However, the author of this article believes that Beijing still maintains an important influence on DPRK and, therefore, could guarantee not only its denuclearization, by suspending trade and aid to this country, but also help DPRK to follow its example of reform and openness, embracing its concept of community of share destiny.

\section{REFERENGES}

Albert, E. (2018, June 25). The China North Korean Relationship. Council on Foreign Relations. https://www. cfr.org/backgrounder/china-north-korearelationship

Bandow. D. (2017, November 8). How to Realistically Solve the North Korean Nuclear Crisis. The Nacional Interest. https://nationalinterest.org/feature/ how-realistically-solve-the-north-korea-crisis-23109

Breuninger, K. (2018, May 15). North Korea cancels meeting with South Korea, threatens to ditch summit with US over military drills. CNBC. https://www.cnbc. com/2018/05/15/north-korea-cancels-scheduled-meeting-with-south-koreareports.html

Chang, C. (2010). The Conclusion of a Peace Treaty is Imperative: The North Korean Perspective. Asia Paper 2010. http://isdp.eu/content/uploads/images/ stories/isdp-main-pdf/2010_choe_the-conclusion-of-a-peace-treaty.pdf

García, P. (2015). Geopolítica del siglo XXI: el factor asiático. Universidad Externado de Colombia. https://doi.org/10.18601/16577558.n21.06

Hassanali, T. (2017, August 1). Why is Obama's Iran nuclear deal good?. Quora. https://www.quora.com/Why-is-Obamas-Iran-nuclear-deal-good

Hecker, S. (2018). A Comprehensive History of North Korea Nuclear Weapons Program. Stanford Center for International Security and Cooperation. https://cisac.fsi. stanford.edu/content/cisac-north-korea

Hurtado, L. (2017, August 11). Una lección iraní para Corea del Norte. El Mundo. http://www.elmundo.es internacional/2017/08/11/ 598c8bb5ca47417a708b45ce.html

Jaramillo C. (2018). Why a Peace Treaty, not just denuclearization, should be the Goal for the Korean Peninsula. Open Canada. https://www.opencanada.org/features/ why-peace-treaty-not-just-denuclearization-should-be-goal-korean-peninsula 
Jinwook, C. (2013). The Trust Building Process and Korean Unification. Korean Institute for National Unification.

Ryan, M. (2017, August 4). Why America 1994 deal with North Korea failed. Independent. https://www.independent.co.uk/voices/north-korea-missiletest-us-1994-agreed-framework-pyongyang-programme-kim-jong-un-donaldtrump-a7876446.html

Sputnik News. (2018, June 12). IAEA verification North Korea denuclearization. Sputnik News. https://sputniknews.com/world/201806121065334294-iaeaverification-korea-denuclearization/

Tong, K. (2018, August 23). North Korea Dismantling key Launch facilities. The Washington Post. https://www.washingtonpost.com/world/asia_pacific/ us-group-north-korea-dismantling-key-launch-site-facilities/2018/07/23/ c9ble8f2-8eee-11e8-ae59-01880eac5fld_story.html?noredir

Toloraya, G. (2017, December 13). Can Diplomacy Work with North Korea? 38 North. https://www.38north.org/2017/12/gtoloraya121317/

Waltz, K, (1999). Teoría de la Política Internacional. Grupo Editor Latinoamericano. Wendt, A. (1999). Social Theory of International Politics. Cambridge University Press. https://doi.org/10.1017/CBO9780511612183

Ying, F. (December 19, 2017). Is There Hope for Peaceful Settlement of Korean Nuclear Issue?. China-US Focus. https://www.chinausfocus.com/peacesecurity/is-there-hope-for-peaceful-settlement-of-korean-nuclear-issue

Zhengqiang, P. (2003). Approach to the North Korean Nuclear Crisis'. KonradAdenauer-Stiftung. https://www.kas.de/de/web/china/publikationen/ einzeltitel/-/content/approach-to-the-north-korean-nuclear-crisis 